\title{
Antimicrobial activity and stability of Prunus mume fruit extract against Streptococcus mutans KCCM 40105 strain
}

\author{
Bok-Seon Kim, So-Mang Kim²,3, Jae-Hee Jeong ${ }^{2}$, Hong-Bi Han², Hui-Won Lee ${ }^{2}$, Cheol-Min Kim², \\ Hyo-Gyeong Woo ${ }^{2}$, Dae-Sub Hwang ${ }^{4}$, Myung-Won Park ${ }^{4}$, Chang-Ki Huh ${ }^{2,3 *}$ \\ ${ }^{1}$ Joyfulfarm Co., Ltd., Jangheeung 59315, Korea \\ ${ }^{2}$ Department of Food Science and Technology, Sunchon National University, Suncheon 57922, Korea \\ ${ }^{3}$ Research Institute of Food Industry, Sunchon National University, Suncheon 57922, Korea \\ ${ }^{4}$ FA INC., Sejong 30068, Korea
}

\section{매실 추출물의 Streptococcus mutans KCCM 40105 균주에 대한 항균활성 및 안정성}

\author{
김복선 ${ }^{1} \cdot$ 김소망 $^{2,3} \cdot$ 정재희 $^{2} \cdot$ 한홍비 $^{2} \cdot$ 이희원 ${ }^{2} \cdot$ 김철민 $^{2} \cdot$ \\ 우효경 ${ }^{2} \cdot$ 황대섭 $^{4} \cdot$ 박명원 $^{4} \cdot$ 허창기 $^{2,3 *}$ \\ ${ }^{1}$ 농업회사법인 주식회사 기쁨농원, ${ }^{2}$ 순천대학교 식품공학과, \\ ${ }^{3}$ 순천대학교 식품산업연구소, ${ }^{4}$ (주)에프에이
}

\begin{abstract}
In this study, natural materials with antibacterial activity against the Streptococcus mutans KCCM 40105 strain were selected, and the most efficient extraction conditions were observed. The active substance was stable under various treatment conditions. Of the $\mathbf{1 0}$ food materials groups, only Prunus mume fruit showed antibacterial activity against $S$. mutans strains. The antimicrobial activity by the various extraction solvents was $18.66 \mathrm{~mm}$ (clear zone diameter) in the ethanol extract and $20.18 \mathrm{~mm}$ in the water extract. Measurements of the antibacterial activity according to the mixing ratio of the two solvents revealed the $30 \%$ ethanol extract to have the highest activity $(20.49 \mathrm{~mm})$. Measurements of the minimum inhibitory concentration (MIC) showed activity at a concentration of $3.0 \mathrm{mg} / \mathrm{mL}$. The stability to heat was observed, but the extract was not active at $\mathrm{pH} 6.0$ or higher. The antimicrobial activity of the $30 \%$ ethanol extract of $P$. mume treated with enzymes was the same with both $10 \mathrm{ppm}$ and $100 \mathrm{ppm}$ of the nine enzymes. On the other hand, the activity tended to decrease slightly at $1,000 \mathrm{ppm}$. The activity of the catazyme enzyme and hydrogen peroxide treatment decreased at the treatment concentration of $100 \mathbf{p p m}$.
\end{abstract}

Key words: Prunus mume, Streptococcus mutans, antibacterial activity, solvent, stability

서 론

일반적으로 충치라고 칭하는 치아 우식증은 구강 질환의 가장 대표적인 질환으로, 치아파괴를 동반한 감염성 질환이며
전 세계적으로 많이 걸리는 구강 내 질병 중 하나이다(Hamada 등, 1984). 충치가 생기는 원인은 여러 가지가 있으나, 그 대 표적인 원인으로는 구강 내에 서식하는 세균에 의하여 발생 하는 것이 대중적으로 알려져 있다. 충치를 유발하는 대표적

*Corresponding author. E-mail : hck1008@sunchon.ac.kr, Phone :+82-61-750-3251, Fax :+82-61-750-3250

Received 23 October 2020; Revised 21 January 2021; Accepted 08 March 2021.

Copyright (c) The Korean Society of Food Preservation.

This is an Open Access article distributed under the terms of the Creative Commons Attribution Non-Commercial License (http://creativecommons.org/licenses/by-nc/4.0) which permits unrestricted non-commercial use, distribution, and reproduction in any medium, provided the original work is properly cited. 
인 균주인 Streptococcus mutans는 gram positive 균주로 통 성 혐기성이며, 치면에 부착, 증식 및 산 생성을 거쳐 치아 우 식을 유발한다. 또한 균체 외 또는 균체 표층에서 치아우식의 유발효소인 glucosyltransferase(GTase)라는 효소를 분비하는 데, GTase는 음식물 중 수크로스(sucrose)를 분해하여 치아면 에 불용성 글루칸(glucan)을 형성하게 된다(Lee 등, 1993). 글 루칸이 구강 내 다른 미생물들과 치아면에 부착하여 치면세 균막(dental plaque)을 생성하면, 치아우식 유발균과 혐기성 세균이 증식하면서 생성된 산에 의해 치아의 칼슘염 상실로 법랑질이 약해져 치아우식이 유발되어 구취, 구내염이 빈번 하게 발생하게 된다. 이러한 원인균의 증식을 억제하기 위해 항생제를 대체할 수 있는 천연물질 개발에 대한 필요성이 증 대되고 있다(Do 등, 2002; Lee 등, 1993; Yun 등, 2007).

현재 인체에 부작용을 유발하지 않는 소재로 유해 미생물 에 대한 선택적 항균력을 가지는 천연 소재로는 녹차 추출물, 황금, 단삼, 소목, 오매, 박하 등 다양한 식물성 소재들이 존 재한다. 그 중 레몬은 피부 상재균에 대한 항균 효과가 보고 된 바 있으며(Kim 등, 2011b), 박하의 경우 비만세포로부터 히스타민의 방출을 억제하는 항알레르기 활성뿐만 아니라, 정 유성분에 대한 항균활성과 구강미생물에 대한 항균 효과를 규명한 논문도 보고되어 있다(Choi 등, 2020; Lee 등, 2002; Shin과 Kim, 1998). 다년생 허브작물인 생강은 인도, 말레이 시아 등 아열대 또는 열대 원산의 초본식물 중 하나로서(Seo, 2017) 병원성 식중독과 치주염 유발 균인 Porphyromonas gingivalis에 대한 항균 작용의 보고가 이루어진 바 있으며 (Lee, 2005; Sheo, 1999), 고추냉이는 유럽 동남부가 원산지 인 다년생 숙근성 식물로 향신료 및 식품 첨가물로 널리 이용 되고 있고, 식용증진, 비타민 $\mathrm{B}_{1}$ 합성증강, 베타 아밀라아제 활성 촉진, 항균작용, 혈전응고 방지, 항산화활성 등의 효과 가 있어 건강식품으로도 각광받고 있다(Park 등, 2009). 또한 구강 내에 서식하는 다양한 미생물에 대한 항균 효과가 보고 된 바 있다(Yu 등, 2006). 울금은 생강과에 속하는 다년생 초 본식물로 열대 아시아 원산으로 인도 · 중국 · 동남아시아 등 지에서 주로 재배하며(Kim 등, 2011a), 항산화작용, 항균성, 항암성, 항돌연변이성, 항종양성에 관한 연구가 보고되어 있 으며, 바질은 주로 잎과 꽃에서 얻어지는 에센셜 오일로 다양 한 효능이 입증된 약용 식물로 알려져 있다(Aye, 2016). 페퍼 민트는 세계적으로 많이 이용되고 있는 허브로서, 추출된 정 유성분에서 대장균과 Salmonella균에 대한 증식 억제 효과가 입증된 바 있으며, 황금은 꿀풀과에 속하는 속썩은풀의 주피 를 제거한 뿌리를 건조한 것으로, 그 약리작용으로는 담즙배 설촉진작용, 항염증작용, 항알레르기작용, 지질대사촉진작용, 충치균에 대한 항균작용 등 다양한 효능으로 알려져 있다 (Moon, 1997). 매화나무가 5-6월경에 맺은 열매를 수확한 매
실은 청매라 불리는데, 해독 및 구충작용이 뛰어나고, 피크린 산 성분이 함유되어 있어 독성 물질을 분해하며, 유기산과 무 기질이 많아 식욕을 돋우고 피로를 풀어주며, 식중독균, 피부 상재균 등에 대한 항균활성 또한 뛰어난 천연 소재로 알려져 있다(Cho 등, 2019; Lee, 2014; Seo 등, 2008). 이와 같이 대 부분의 천연 소재는 병원성 식중독균, 피부 상재균 등에 대한 항균효과를 규명하는 데 치우쳐 있어 구강세균에 대한 활성 을 확인하는 추가적인 연구가 필요한 실정이다. 따라서 본 연 구에서는 항균제 역할을 수행할 수 있는 천연물을 검색하여 구강세균에 대한 활성을 검토하고, 선정된 천연물을 이용하 여 추출조건 탐색, 충치균에 대한 항균활성 및 추출물의 안정 성 평가를 실시하여 다양한 제품들에 응용할 수 있는 기반을 마련하고자 하였다.

\section{재료 및 방법}

\section{실험재료 및 시약}

항균활성 소재 선발 후보군에서 레몬은 (주)올내추럴(Paju, Korea), 박하, 페퍼민트, 황금은 (주보다(Hwaseong, Korea), 와사비는 (주대저(Busan, Korea), 울금은 진도농협울금가공사 업소(Jindo, Korea), 생강은 청운유통(Jincheon, Korea), 바질 은 (주가보식품(Namyangju, Korea), 매실종자는 2019년 6월 에 전라남도 순천시 해룡면에서 수확한 매실 열매에서 종자 만을 채취하였으며, 매실 열매 동결건조 분말은 (주)산마을 (Changnyeong, Korea)에서 구매하여 실온보관하며 사용하였 다. 항균활성 소재 후보군의 정보는 Table 1 과 같다. 시약은 ethanol(94.5\%), $n$-hexane(95\%), ethyl ether(99\%), ethyl acetate (99\%), chloroform(99.5\%), n-butanol(99\%)은 Daejung사 (Siheung, Korea)의 것을 구입하여 사용하였다. 유기물 분해 효소와 산화 효소제인 Fungamyl(Fun), Termamyl(Ter), Secura (Sec), Lactozym(Lac), Maltoginase(Mal), Invertase(Inv), Flavourzyme(Fla), Alcalase(Alc), Lipozyme(Lip), Catazyme (Cat)는 (주)바이오시스(Haeundae, Korea)에서 구입하였고 산 화제인 hydrogen peroxide(Hyp)는 Daejung사(Siheung, Korea) 의 것을 구입하여 사용하였다.

\section{실험 균주 및 배지}

본 실험에 사용한 균주는 Streptococcus mutans KCCM 40105로 한국미생물보존센터에서 분양받아 액체배지에 활성 화시킨 후, 균주 1 백금이를 취해 $10 \mathrm{~mL}$ Brain Heart Infusion broth의 균 생육배지에 접종하고, $37^{\circ} \mathrm{C}$ 에서 3 회 계대배양하 여 사용하였다. 배지는 Brain Heart Infusion broth는 Difco사 (Detroit, MI, USA)의 것을 구입하여 사용하였고, agar는 Daejung사의 것을 구입하여 사용하였다. 
Table 1. List of natural materials for antimicrobial experiments

\begin{tabular}{ccc}
\hline Scientific name & English name & Part of used \\
\hline Citrus limon & Lemon & Fruit \\
Mentha piperascens & Mint & Leaf \\
Eutrema japonicum & Wasabi & Root \\
Curcuma longa & Ulgeum & Root \\
Zingiber officinale & Ginger & Rhizome \\
Ocimum basilicum & Basil & Leaf \\
Mentha species & Peppermint & Leaf \\
Scutellaria baicalensis & Skullcap & Root \\
Prunus mume & Plum seed & Seed \\
Prunus mume & Plum & Fruit \\
\hline
\end{tabular}

S. mutans KCCM 40105 균주의 항균활성 식품소재 탐색

항균활성의 시험용 평판배지는 Brain Heart Infusion agar 를 멸균하여 petri dish에 $15 \mathrm{~mL}$ 씩 분주하여 응고시키고, 중 층용 배지를 약 $10 \mathrm{~mL}$ 시험관에 분주하여 멸균한 후, 활성화 시킨 균주 배양물 $0.5 \mathrm{~mL}$ 를 무균적으로 첨가하여 잘 혼합하 고, 기존에 응고시켜둔 배지 위에 분주한 뒤 고르게 응고시키 고, 2 중의 균 접종 평판배지를 만들어 사용하였다. 각각의 소 재별 항충치균 활성 측정은 한천배지확산법(agar dilution method)(Seo 등, 2008)으로 측정하였다. 즉, 각각의 후보군 추출물을 paper disc(Advantec $8 \mathrm{~mm}$, Toyo Roshi, Tokyo, Japan)에 4번에 나누어 흡수시킨 후, 추출용매를 무균적인 조 건 하에서 완전히 날려 보낸 다음, 시험용 중층배지에 밀착시 키고, $37^{\circ} \mathrm{C}$ 에서 20-24시간 동안 배양한 다음, paper disc 주변 의 clear zone 직경 $(\mathrm{mm})$ 을 측정하여 $S$. mutans $\mathrm{KCCM}$ 40105 균주의 항균활성 천연 소재를 선발하였다.

\section{추출 용매 및 ethanol 농도별 항균활성 측정}

추출용매별 항균활성 측정은 매실 열매 분말 시료 $5 \mathrm{~g}$ 에 $n$-hexane, ether, ethyl acetate, ethanol, water를 각각 $50 \mathrm{~mL}$ 씩 첨가하고, 24시간 동안 진탕 추출한 후 여과하여 한천배지확 산법(Seo 등, 2008)으로 clear zone 생성 유무를 확인하였다.

Ethanol 농도별 항균활성 측정은 시료 $5 \mathrm{~g}$ 에 ethanol 농도 를 $0 \%, 30 \%, 50 \%, 70 \%, 94.5 \%$ 로 각각 조정한 용매 $50 \mathrm{~mL}$ 씩을 첨가하여 추출한 후 여과하여 항균활성을 비교하였다.

\section{용매 분획물별 항균활성 측정}

매실 추출물을 Accelerated Solvent Extractor(Dionex, USA)에 의한 용매별 분획으로 $n$-hexane, chloroform, ethyl acetate, $n$-butanol, water로 연속추출한 후 각 분획물을 농축 하여 시료로 사용하였다. 용매별로 분획 후 농축한 시료를 paper disc에 4번에 나누어 흡수시킨 후, 추출용매를 무균적 인 조건 하에서 완전히 날려 보낸 다음, 시험용 중층배지에 밀착시키고, $37^{\circ} \mathrm{C}$ 에서 $20-24$ 시간 동안 배양한 다음 paper disc 주변의 clear zone 직경 $(\mathrm{mm})$ 을 측정하여 항균활성을 비 교하였다.

\section{최소저해농도(MIC) 측정}

시료의 최소저해농도(minimum inhibitory concentration, $\mathrm{MIC})$ 는 한천배지확산법( $\mathrm{Seo}$ 등, 2008)으로 측정하였다. 시 료 $5 \mathrm{~g}$ 에 $30 \%$ ethanol $50 \mathrm{~mL}$ 를 각각 첨가하여 추출한 후 여과하여 사용하였고, paper disc에 설정한 고형물 함량에 맞 춰 추출물을 무균조건 하에서 완전히 날려 보낸 다음, 시험용 중층배지에 놓아 밀착시키고, $37^{\circ} \mathrm{C}$ 에서 20-24시간 동안 배양 한 다음 paper disc 주변의 clear zone의 생성 유무를 확인하 였다.

\section{열 및 $\mathrm{pH}$ 안정성 측정}

추출물의 열 안정성은 $30 \%$ ethanol 추출물을 $60-121^{\circ} \mathrm{C}$ 까 지의 온도에서 열처리하였으며 $60^{\circ} \mathrm{C}, 80^{\circ} \mathrm{C}, 100^{\circ} \mathrm{C}$ 에서 각각 1 시간씩 열처리하였고, $121^{\circ} \mathrm{C}$ 에서는 15 분간 열처리한 후 열 처리를 하지 않은 추출물을 대조구로 설정한 다음 항균활성 을 비교하였다.

$\mathrm{pH}$ 안정성은 $30 \%$ ethanol 추출물을 $1 \mathrm{~N} \mathrm{NaOH}$ 와 $1 \mathrm{~N}$ $\mathrm{HCl}$ 으로 $\mathrm{pH} 2, \mathrm{pH} 4, \mathrm{pH} 6, \mathrm{pH} 8, \mathrm{pH} 10$ 으로 각각 $\mathrm{pH}$ 를 조절한 후, $\mathrm{pH}$ 를 조절하지 않은 추출물을 대조구로 하여 항 균활성을 비교하였다.

\section{산화효소와 과산화수소 처리에 따른 안정성 평가}

산화효소와 과산화수소 처리에 따른 항균활성은 매실 열 매 $30 \%$ ethanol 추출물에 산화효소와 과산화수소를 각각 10 $\mathrm{ppm}, 100 \mathrm{ppm}, 1,000 \mathrm{ppm}$ 의 농도로 맞추어 각각 처리한 다 음 30 분간 방치하고, 산화제 처리를 하지 않은 추출물을 대조 구로 설정하여 항균활성을 비교하였다.

산화효소와 과산화수소 처리 온도에 따른 항균활성을 측정 하기 위해 매실 열매 $30 \%$ ethanol 추출물에 산화효소와 과산 화수소를 각각 $100 \mathrm{ppm}$ 의 농도로 맞추어 처리한 다음 $20^{\circ} \mathrm{C}$, $25^{\circ} \mathrm{C}, 30^{\circ} \mathrm{C}, 35^{\circ} \mathrm{C}, 40^{\circ} \mathrm{C}$ 에서 각각 열처리를 30 분간 처리하고, 효소 처리를 하지 않은 추출물을 대조구로 설정하여 항균활 성을 비교하였다.

\section{유기물 분해효소 처리에 따른 안정성 평가}

유기물 분해효소 농도별 처리에 따른 항균활성의 측정은 
매실 열매 $30 \%$ ethanol 추출물에 9가지 효소를 각각 $10 \mathrm{ppm}$, $100 \mathrm{ppm}, 1,000 \mathrm{ppm}$ 의 농도로 맞추어 각각 처리한 다음, 30 분간 방치하고, 효소 처리를 하지 않은 추출물을 대조구로 설 정하여 항균활성을 비교하였다.

유기물 분해효소 온도 처리에 따른 항균활성은 매실 열매 $30 \%$ ethanol 추출물에 9 가지 효소를 각각 $100 \mathrm{ppm}$ 의 농도로 맞추어 처리한 다음, $20^{\circ} \mathrm{C}, 25^{\circ} \mathrm{C}, 30^{\circ} \mathrm{C}, 35^{\circ} \mathrm{C}, 40^{\circ} \mathrm{C}$ 에서 각각 열처리를 30 분간 처리하고, 효소 처리를 하지 않은 추출물을 대조구로 설정하여 항균활성을 비교하였다.

\section{통계분석}

실험결과는 3 회 반복 측정하여 SPSS program(26, IBM Corp., Armonk, NY, USA)을 사용하였고, mean $\pm \mathrm{SD}$ 를 구하 였으며, Duncan's multiple range test로 시료간의 유의차를 분석하였다.

\section{결과 및 고찰}

\section{Streptococcus mutans 균주의 항균활성 식품 소재 선발}

10종(레몬, 박하, 페퍼민트, 황금, 와사비, 울금, 생강, 바 질, 매실종자, 매실 열매)의 식품 소재별 S. mutans 균주에 대한 항균활성 측정 결과는 다음 Table 2 와 같다. 측정 결과, 후보군 중 유일하게 매실에서 활성이 나타났고, 나머지 9종 은 활성이 나타나지 않았다. 본 연구 설계시 사전 조사(Aye,

Table 2. Antimicrobial activities of different plant extracts against Streptococcus mutans KCCM 40105

\begin{tabular}{ccc}
\hline \multirow{2}{*}{ Sample } & \multicolumn{2}{c}{ Clear zone on plate $(\mathrm{mm})$} \\
\cline { 2 - 3 } Citrus limon & Ethanol extract & Water extract \\
\hline Mentha piperascens & $-{ }^{1)}$ & - \\
Eutrema japonicum & - & - \\
Curcuma longa & - & - \\
Zingiber officinale & - & - \\
Ocimum basilicum & - & - \\
Mentha species & - & - \\
Scutellaria baicalensis & - & - \\
Prunus mume seed & - & $20.90 \pm 0.10$ \\
Prunus mume & $20.53 \pm 0.75^{2)}$ & \\
\hline${ }^{10}$ Not detected. & &
\end{tabular}

2016; Cho 등, 2019; Kim 등, 2011a; Kim 등, 2011b; Lee 등, 2006; Moon, 1997; Park 등, 2009; Seo, 2017; Sheo, 1999; Shin과 Kim, 1998)를 통해 기존 항균활성이 높다고 보 고된 소재를 후보군으로 선발해서 실험을 진행하였지만, $S$. mutans 균주에는 매실 ethanol 추출물과 water 추출물을 제외 하고는 활성을 보이지 않았다. 매실의 활성은 ethanol 추출물 이 $20.53 \mathrm{~mm}$, water 추출물이 $20.90 \mathrm{~mm}$ 의 높은 활성이 나타 났다. Kim 등(2003a)에 따르면 대추, 구기자, 매실, 오미자의 항균활성을 비교한 결과, 매실의 활성이 가장 높게 나왔다고 보고하였다. Jung 등(2014)에 따르면 매실이 S. mutans의 증 식을 억제시키는 효과를 확인할 수 있었다고 보고하였다. 따 라서 매실을 S. mutans 균주의 항균활성 식품 소재로 선발하 여 다음 실험을 진행하였다.

\section{매실의 항균활성 선행 연구자료 검색 비교}

S. mutans 균주의 항균활성 효과 식품 소재 선발 과정에서 최종 선발된 매실은 다양한 항균활성이 있다고 보고되어 있 다. 따라서 기존 매실에 대한 결과와 본 연구 결과의 비교 분석을 위해 매실의 항균활성에 대한 선행연구 자료를 검색 한 결과는 Table 3 과 같다. 매실 원료를 대상으로 항균활성을 평가한 결과에서 $\mathrm{Seo}$ 등(2008)에 따르면 매실 water 추출물 이 Bacillus cereus에서는 11.2-12.8 mm, Staphylococcus aureus의 경우 11.1-12.7 mm의 활성이 나타났고, Park 등 (2007)의 보고에서는 매실 ethanol 추출물이 B. cereus 38.0 $\mathrm{mm}, S$. aureus는 $36.7 \mathrm{~mm}$ 로 나타났다고 보고하였다. 이와 같은 결과를 볼 때 매실 원료를 대상으로 하는 항균활성도는 에탄올 용매 추출물이 효과적이라는 것을 확인할 수 있었다. 하지만 본 연구에서는 water 추출물 $(20.92 \mathrm{~mm})$ 과 ethanol 추 출물 $(20.53 \mathrm{~mm})$ 의 활성도 차이가 크지 않았다. 이와 같은 이 유는 저해하고자 하는 균주의 종류가 달라 활성의 영향력이 다른 것으로 판단된다. 매실 농축액을 대상으로 항균활성을 평가한 선행 연구를 살펴보면 Choi 등(2004)은 B. cereus에 서는 $25.0 \mathrm{~mm}, S$. aureus의 경우 $12.5 \mathrm{~mm}$ 의 활성이 나타났 다고 보고하였다. 또한 Ko와 $\mathrm{Yang}(2009)$ 의 보고에서는 매실 당절임에서 B. cereus는 $20.0 \mathrm{~mm}, S$. aureus는 $17.6 \mathrm{~mm}$ 의 활성이 있다고 보고하여 다양한 매실 제품에 대한 활성도를 확인하였다. 또한 Lee(2014)는 매실 추출물이 S. mutans 균주 에 효과가 있다고 보고하였다. 하지만 항균활성 결과를 볼 때, Lee(2014)의 연구에서는 매실 methanol 추출물이 S. mutans 균주에 $13.67 \mathrm{~mm}$ 의 활성을 보였고, 본 연구에서의 ethanol 추출물 $20.53 \mathrm{~mm}$, water 추출물 $20.90 \mathrm{~mm}$ 의 활성을 보여 Lee(2014) 연구에 비해 활성이 높게 나타났다. 이러한 이유 는 사용된 용매에 차이가 있으며, 추출 조건 또한 상이해서 
Table 3. Previous research data on the antimicrobial activity of $P$. mume fruit

\begin{tabular}{|c|c|c|c|c|c|}
\hline Product type & Strain & Extraction condition & Extraction solvent & $\begin{array}{l}\text { Clear zone on plate } \\
(\mathrm{mm})\end{array}$ & Reference \\
\hline \multirow{5}{*}{$\begin{array}{c}P . \text { mume } \\
\text { (raw material) }\end{array}$} & B. cereus & Ordinary temperature & Water extract & $11.2-12.8$ & Seo et al. (2008) \\
\hline & B. cereus & Ordinary temperature & Ethanol extract & $38.0 \pm 1.7$ & Park et al. (2007) \\
\hline & S. aureus & Ordinary temperature & Water extract & $11.1-12.7$ & Seo et al. (2008) \\
\hline & S. aureus & Ordinary temperature & Ethanol extract & $36.7 \pm 3.1$ & Park et al. (2007) \\
\hline & S. mutans & Ordinary temperature & Methanol extract & $13.67 \pm 0.29$ & Lee (2014) \\
\hline \multirow{2}{*}{$\begin{array}{c}P . \text { mume } \\
\text { (concentration) }\end{array}$} & B. cereus & Ordinary temperature & Water extract & $25.0 \pm 0.45$ & Choi et al. (2004) \\
\hline & S. aureus & Ordinary temperature & Water extract & $12.5 \pm 0.50$ & Choi et al. (2004) \\
\hline \multirow{2}{*}{$\begin{array}{l}\text { P. mume } \\
\text { (sugaring) }\end{array}$} & B. cereus & Ordinary temperature & Water extract & 20.0 & Ko and Yang (2009) \\
\hline & S. aureus & Ordinary temperature & Water extract & 17.6 & Ko and Yang (2009) \\
\hline
\end{tabular}

나온 결과로 판단된다.

\section{추출 방법에 따른 항균활성}

추출 용매별 매실의 S. mutans 균주에 대한 항균활성을 측 정한 결과는 Table $4 \mathrm{~A}$ 및 Fig. $1 \mathrm{~A}$ 와 같다. 매실의 $n$-hexane 추출물에서는 clear zone이 관찰되지 않았고, ether 추출물은 $9.75 \mathrm{~mm}$, ethyl acetate 추출물에서는 $9.99 \mathrm{~mm}$ 의 크기로 생 육저해환이 관찰되었다. Ethanol 추출물에서는 $18.66 \mathrm{~mm}$, water 추출물에서는 $20.18 \mathrm{~mm}$ 로 다른 추출 용매보다 높은 항 균활성을 가지는 것으로 확인되었다. Seo 등(2008)의 보고에 따르면 병원성 미생물 6종의 항균활성 측정 결과, methanol
추출물이 가장 높은 활성을 보였고, 다른 용매에 비해 water 추출물이 비교적 낮게 나타났다고 보고해 본 연구 결과와 다 소 차이를 보여, 활성 물질이 다를 수 있는 가능성을 확인하 였다. 본 연구 결과를 통해 S. mutans 균주에 대한 매실 소재 의 항균활성 실험의 최적 추출 조건을 확인하기 위해 ethanol 추출 농도에 따른 항균활성 실험을 진행하였다. 매실의 ethanol 추출 농도별 S. mutans 균주에 대한 항균활성 측정 결과는 Table $4 \mathrm{~B}$ 및 Fig. $1 \mathrm{~B}$ 와 같다. Water 추출물과 ethanol 추출 농도를 $30 \%, 50 \%, 70 \%$ 및 $94.5 \%$ 로 조정해서 추출한 추출물의 항균활성을 측정한 결과, water 추출물은 20.29 $\mathrm{mm}$ 의 활성이 나타났고, $30 \%$ ethanol 추출물은 $20.49 \mathrm{~mm}$,

Table 4. Antimicrobial activity of various extraction methods and fractions of $P$. mume fruit against Streptococcus mutans KCCM 40105

(A)

\begin{tabular}{|c|c|c|c|c|c|}
\hline \multirow{2}{*}{ Strain } & \multicolumn{5}{|c|}{ Clear zone on plate $(\mathrm{mm})$} \\
\hline & $n$-Hexane & Ether & Ethyl acetate & Ethanol & Water \\
\hline S. mutans & -1) & $9.75 \pm 0.00^{2 \mathrm{c}) 33}$ & $9.99 \pm 2.01^{\mathrm{b}}$ & $18.66 \pm 1.33^{\mathrm{a}}$ & $20.18 \pm 1.29^{\mathrm{a}}$ \\
\hline \multicolumn{6}{|l|}{ (B) } \\
\hline Strain & $0 \%$ & $30 \%$ & $50 \%$ & $70 \%$ & $94.5 \%$ \\
\hline S. mutans & $20.29 \pm 1.79^{\mathrm{a}}$ & $20.49 \pm 2.06^{\mathrm{a}}$ & $19.09 \pm 1.25^{\mathrm{a}}$ & $19.02 \pm 3.63^{\mathrm{a}}$ & $19.65 \pm 1.04^{\mathrm{a}}$ \\
\hline
\end{tabular}

(C)

\begin{tabular}{cccccc}
\hline Strain & $n$-Hexane & Chloroform & Ethyl acetate & $n$-Butanol & Water \\
\hline$S$. mutans & - & - & $12.74 \pm 1.71^{\mathrm{b}}$ & $20.62 \pm 2.34^{\mathrm{a}}$ & $17.77 \pm 0.86^{\mathrm{a}}$ \\
\hline
\end{tabular}

A, antimicrobial activities by extraction solvents; B, antimicrobial activities by ethanol extraction concentration; C, antimicrobial activities by fraction extraction.

${ }^{1)}$ Not detected.

${ }^{2)}$ All values are mean \pm SD $(n=3)$.

${ }^{3)}$ Means in the same row followed by different letters are significantly different $(\mathrm{p}<0.05, a>b>c)$. 


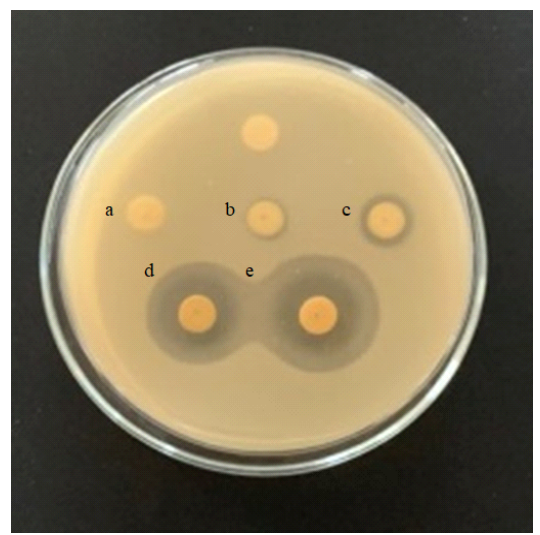

(A)

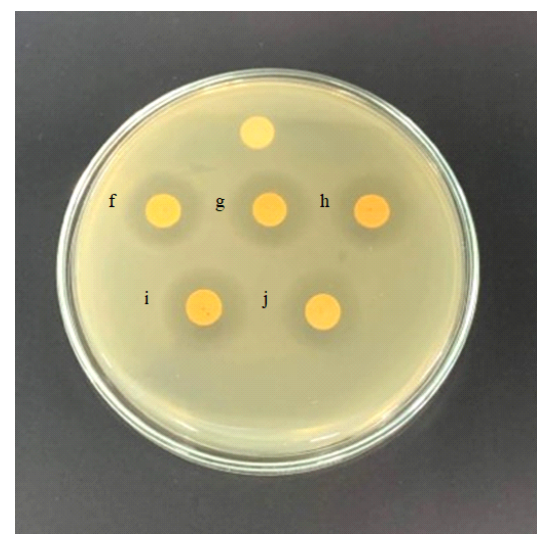

(B)

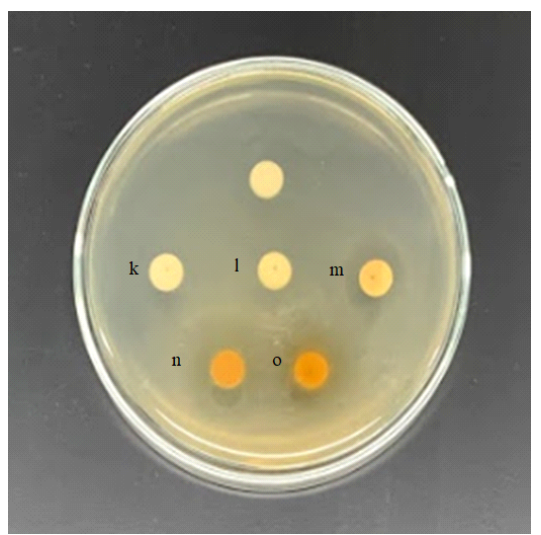

(C)

Fig. 1. Pictures of antimicrobial activities by extraction methods and fractions of $P$. mume fruit against Streptococcus mutans KCCM 40105.

A, antimicrobial activities by extraction solvents; B, antimicrobial activities by ethanol extraction concentration; C, antimicrobial activities by fraction extraction.

a, $n$-hexane extract; b, ether extract; c, ethyl acetate extract; d, ethanol extract; e, water extract; f, water extract; g, 30\% ethanol extract; h, 50\% ethanol extract; i, $70 \%$ ethanol extract; j, 94.5\% ethanol extract; $\mathrm{k}$, hexane fraction; 1 , chloroform fraction; m, ethyl acetate fraction; $\mathrm{n}, n$-butanol fraction; $\mathrm{o}$, water fraction.

$50 \%$ ethanol 추출물은 $19.09 \mathrm{~mm}, 70 \%$ ethanol 추출물은 $19.02 \mathrm{~mm}, 94.5 \%$ ethanol 추출물은 $19.65 \mathrm{~mm}$ 로, 매실의 $30 \%$ ethanol 추출물 농도에서 가장 높은 활성을 보였으나, 유 의적 차이는 보이지 않았다. 이러한 결과를 통해 매실의 $S$. mutans 균주에 대한 항균활성의 최소저해농도(MIC) 실험과 S. mutans 균주에 대한 매실 활성 물질의 안정성을 확인하기 위한 추출 농도는 $30 \%$ ethanol 추출물로 선정하였다. 매실 $30 \%$ ethanol 추출물의 용매 분획물별 S. mutans 균주에 대한 항균활성 측정 결과는 Table $4 \mathrm{C}$ 및 Fig. $1 \mathrm{C}$ 와 같다. 분획물별 활성 측정 결과 hexane층과 chloroform층에서는 활성을 보이 지 않았고, ethyl acetate층에서는 $12.74 \mathrm{~mm}$, n-butanol층은 $20.62 \mathrm{~mm}$, water층에서는 $17.77 \mathrm{~mm}$ 의 활성을 보여 n-butanol 층이 가장 높은 활성을 보였다. Lim과 Lee(1999)의 연구에 따르면 세균 8 종에 대한 매실 추출물의 용매별 분획물 중 ethyl acetate층과 butanol층이 활성이 높았고, water층이 그 다음으로 활성이 높았다고 보고하였다. 또한 Yoon 등(2005) 의 보고에서도 병원성 식중독균 6 종에 대한 매실 추출물의 분획물중 ethyl acetate층과 butanol층 활성이 높았다고 보고
해 본 연구 결과와 약간의 차이를 보였다. 이는 매실의 항균 활성 물질이 균주별로 다를 수 있는 가능성을 제시하는 내용 이며, 본 연구의 경우 극성 용매 추출물에 항균활성 물질이 잠재되어 있을 것으로 사료된다.

\section{최소저해농도(MIC)}

매실 30\% ethanol 추출물의 S. mutans 균주에 대한 최소저 해농도 측정 결과는 다음 Table 5 에서 보는 바와 같다. 매실 $30 \%$ ethanol 추출물의 첨가 농도별 항균활성을 측정한 결과, 1.0 및 $2.0 \mathrm{mg} / \mathrm{mL}$ 농도에서는 활성이 나타나지 않았고, 3.0 $\mathrm{mg} / \mathrm{mL}$ 농도부터 활성이 나타났다. Lee 등(2017)은 오배자 추 출물의 최소저해농도를 측정한 결과, Bacillus cereus에서 11.2 $\mathrm{mg} / \mathrm{mL}$, Clostridium perfringens에서 $2.4 \mathrm{mg} / \mathrm{mL}$, Escherichia coli에서 $9.1 \mathrm{mg} / \mathrm{mL}$, Listeria monocytogenes에서 $11.1 \mathrm{mg} / \mathrm{mL}$, S. aureus에서 $2.4 \mathrm{mg} / \mathrm{mL}$, Salmonella typhi에서 $4.7 \mathrm{mg} / \mathrm{mL}$, Vibrio parahaemolyticus에서 $2.4 \mathrm{mg} / \mathrm{mL}$ 의 농도로 나타났다 고 보고해, 본 연구에서의 S. mutans 균주에 대한 매실 $30 \%$ ethanol 추출물의 최소저해농도와 비슷한 결과를 보였다.

Table 5. Minimum inhibitory concentration (MIC) of $P$. mume fruit $30 \%$ ethanol extract against Streptococcus mutans $\mathrm{KCCM} 40105$

\begin{tabular}{ccccccc}
\hline \multirow{2}{*}{ Strain } & \multicolumn{5}{c}{ Clear zone on plate $(\mathrm{mm})$} & \\
\cline { 2 - 7 } & 1.0 & 2.0 & 3.0 & 4.0 & 5.0 & $(\mathrm{mg} / \mathrm{mL})$ \\
\hline S. mutans & $-1)$ & - & $9.21 \pm 1.16^{2) \mathrm{b3}}$ & $9.78 \pm 0.77^{\mathrm{b}}$ & $12.10 \pm 1.13^{\mathrm{a}}$ & 3.0 \\
\hline
\end{tabular}

\footnotetext{
${ }^{1)}$ Not detected.

${ }^{2)}$ All values are mean $\pm \mathrm{SD}(\mathrm{n}=3)$.

${ }^{3)}$ Means in the same row followed by different letters are significantly different $(\mathrm{p}<0.05, \mathrm{a}>\mathrm{b})$.
} 


\section{열 및 $\mathrm{pH}$ 안정성}

매실 $30 \%$ ethanol 추출물의 S. mutans 균주에 대한 열 안 정성을 측정한 결과는 Table $6 \mathrm{~A}$ 및 Fig. $2 \mathrm{~B}$ 와 같다. 매실 $30 \%$ ethanol 추출물을 $60^{\circ} \mathrm{C}, 80^{\circ} \mathrm{C}$ 및 $100^{\circ} \mathrm{C}$ 에서는 각각 1 시 간씩 열처리하고, $121^{\circ} \mathrm{C}$ 에서는 15 분간 열처리한 후 S. mutans 균주에 확산시켜 생육저해환의 크기를 측정하였다. 그 결과, $60^{\circ} \mathrm{C}$ 에서 $18.88 \mathrm{~mm}, 80^{\circ} \mathrm{C}$ 에서 $19.85 \mathrm{~mm}, 100^{\circ} \mathrm{C}$ 에서 18.71 $\mathrm{mm}, 121^{\circ} \mathrm{C}$ 에서 $18.73 \mathrm{~mm}$ 로 대조구와 비교해 생육저해환의 유의적 차이를 보이지 않았다. $\mathrm{Ha}$ 등(2006)의 보고에서는 매 실 추출물을 $40-120^{\circ} \mathrm{C}$ 의 다양한 열처리를 통해 활성을 측정 한 결과, 열에 안정하였다고 보고하였다. 하지만 Choi 등 (2004)의 보고에서는 매실 농축액에 다양한 열처리를 통해 활성을 측정한 결과 가열 온도가 증가함에 따라 활성이 떨어 진다고 보고하였다. 이처럼 소재에 포함된 항균활성 물질이 열에 안정한 물질일 수도 있고, 불안정한 물질도 있으며, 본 연구에서 실시한 S. mutans 균주에 대한 매실의 항균활성 물 질은 열에 안정한 물질임을 확인하였다.

매실 $30 \%$ ethanol 추출물의 $\mathrm{pH}$ 안정성 측정 결과는 Table $6 \mathrm{~B}$ 및 Fig. $2 \mathrm{~B}$ 와 같다. 매실 $30 \%$ ethanol 추출물을 $1 \mathrm{~N}$ $\mathrm{NaOH}$ 와 $1 \mathrm{~N} \mathrm{HCl}$ 으로 $\mathrm{pH} 2, \mathrm{pH} 4, \mathrm{pH} 6, \mathrm{pH} 8$ 및 $\mathrm{pH} 10$ 으 로 각각 조절한 후 S. mutans 균주에 대한 항균활성을 확인하 였다. 측정 결과, $\mathrm{pH} 2$ 시료구에서는 $15.96 \mathrm{~mm}, \mathrm{pH} 4$ 시료 구에서는 $11.86 \mathrm{~mm}$ 로 생육저해환이 나타났으나, $\mathrm{pH} 6, \mathrm{pH}$ 8 및 $\mathrm{pH} 10$ 구간의 시료구에서는 활성이 나타나지 않았다. $\mathrm{Ha}$ 등(2006)의 보고에서는 매실 추출물을 $\mathrm{pH}$ 3-11로 조정하 여 세균 2종에 대한 활성을 측정한 결과, 모든 시료구에서 활 성을 보여 활성물질이 $\mathrm{pH}$ 에 안정한 결과를 보였다고 보고하 였고, Choi 등(2004)의 보고에서는 매실 농축액을 $\mathrm{pH} \mathrm{3,pH}$

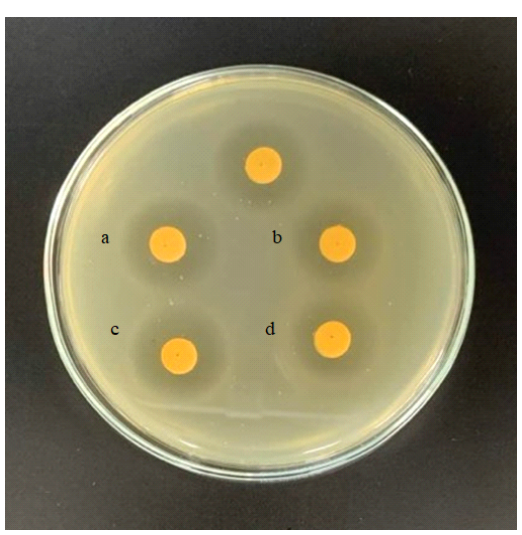

(A)

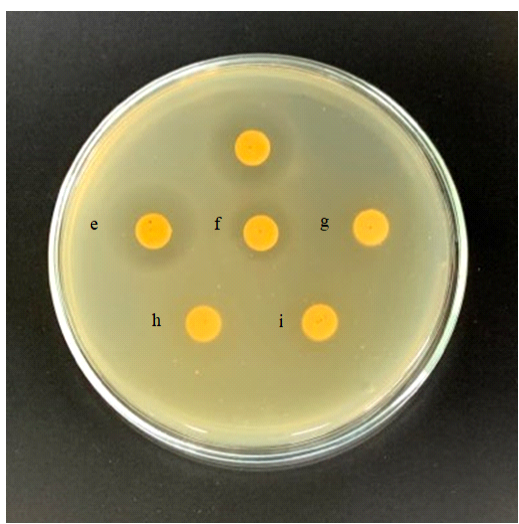

(B)

Fig. 2. Pictures of heat and pH stability of $P$. mume fruit $30 \%$ ethanol extract against Streptococcus mutans KCCM 40105.

A, heat stability; B, pH stability.

a, $60^{\circ} \mathrm{C} ; \mathrm{b}, 80^{\circ} \mathrm{C} ; \mathrm{c}, 100^{\circ} \mathrm{C} ; \mathrm{d}, 121^{\circ} \mathrm{C} ; \mathrm{e}, \mathrm{pH} 2 ; \mathrm{f}, \mathrm{pH} 4 ; \mathrm{g}, \mathrm{pH} 6 ; \mathrm{h}$, $\mathrm{pH} 8 ; \mathrm{i}, \mathrm{pH} 10$.

Table 6. Heat and pH stability of $P$. mume fruit $30 \%$ ethanol extract against Streptococcus mutans $\mathrm{KCCM} 40105$

(A)

\begin{tabular}{|c|c|c|c|c|c|c|}
\hline \multirow{3}{*}{ Strain } & \multicolumn{6}{|c|}{ Clear zone on plate $(\mathrm{mm})(11.48 \mathrm{mg} / \mathrm{mL})$} \\
\hline & \multirow{2}{*}{ Control } & \multicolumn{5}{|c|}{ Heating temperature } \\
\hline & & $60^{\circ} \mathrm{C}$ & $80^{\circ} \mathrm{C}$ & & $100^{\circ} \mathrm{C}$ & $121^{\circ} \mathrm{C}$ \\
\hline S. mutans & $19.34 \pm 3.26^{1) \mathrm{a} 2)}$ & $18.88 \pm 2.53^{\mathrm{a}}$ & $19.85 \pm 3.01^{\mathrm{a}}$ & & $18.71 \pm 2.75^{\mathrm{a}}$ & $18.73 \pm 1.95^{\mathrm{a}}$ \\
\hline \multicolumn{7}{|l|}{ (B) } \\
\hline \multirow{2}{*}{ Strain } & \multirow{2}{*}{ Control } & \multicolumn{5}{|c|}{$\mathrm{pH}$} \\
\hline & & 2 & 4 & 6 & 8 & 10 \\
\hline S. mutans & $20.70 \pm 13.52^{\mathrm{a}}$ & $15.96 \pm 2.90^{\mathrm{a}}$ & $11.86 \pm 1.69^{\mathrm{a}}$ & $-3)$ & - & - \\
\hline
\end{tabular}

A, antimicrobial activities by heat treatments; $\mathrm{B}$, antimicrobial activities by $\mathrm{pH}$ treatments.

1) All values are mean $\pm \mathrm{SD}(\mathrm{n}=3)$.

${ }^{2}$ Means in the same row followed by different letters are significantly different $(p<0.05)$.

${ }^{3)}$ Not detected. 
7, $\mathrm{pH} 11$ 이 되도록 처리한 후 세균과 효모 8종에 대한 활성 을 측정한 결과, $\mathrm{pH}$ 가 높아질수록 항균활성이 감소하였다고 보고하였다. 이러한 결과는 소재별 항균활성물질이 $\mathrm{pH}$ 에 민 감하게 반응한다는 의미를 갖는 내용이며, 본 연구에서의 매 실 30\% ethanol 추출물에 포함된 활성물질 또한 $\mathrm{pH} 2$ 및 4 범위에서는 활성을 보였으나, $\mathrm{pH}$ 6-10의 범위에서는 활성이 나타나지 않은 것으로 보아, 매실에 함유되어 있는 항균물질 도 $\mathrm{pH}$ 에 영향을 받는 물질임을 추측할 수 있다.

\section{산화효소와 과산화수소 처리에 따른 안정성}

S. mutans 균주에 항균활성 효과를 갖는 매실 $30 \%$ ethanol 추출물에 포함된 항균 물질이 산화효소와 과산화수소 처리에 안정성이 있는지를 확인하기 위해 산화효소인 catazyme과 과 산화수소를 매실 $30 \%$ ethanol 추출물에 아래와 같은 두 조건 으로 첨가하고 반응시킨 후 항균활성을 확인하였다. catazyme 효소와 과산화수소의 처리 농도에 따른 항균활성 측정 결과 는 Table $7 \mathrm{~A}$ 와 같다. 측정 결과, 매실 $30 \%$ ethanol 추출물에 catazyme효소와 과산화수소를 각각 $10 \mathrm{ppm}$ 농도로 처리했 을 때 두 시료구 모두 항균활성이 높아졌고, $100 \mathrm{ppm}$ 의 농도 에서는 catazyme효소 처리구는 대조구에 비해서 활성이 감

Table 7. Effect of catazyme and hydrogen peroxide treatments on antimicrobial activity of $P$. mume fruit $30 \%$ ethanol extract against Streptococcus mutans KCCM 40105

(A)

\begin{tabular}{|c|c|c|}
\hline \multirow{2}{*}{ Sample } & \multicolumn{2}{|c|}{ Clear zone on plate $(\mathrm{mm})(11.48 \mathrm{mg} / \mathrm{mL})$} \\
\hline & $\mathrm{Cat}^{1)}$ & Нyp \\
\hline Control & $20.39 \pm 1.29^{2 \mathrm{ab} 33}$ & $20.41 \pm 1.44^{\mathrm{ab}}$ \\
\hline $10 \mathrm{ppm}$ & $23.63 \pm 1.88^{\mathrm{a}}$ & $23.08 \pm 1.22^{\mathrm{a}}$ \\
\hline $100 \mathrm{ppm}$ & $16.81 \pm 1.52^{\mathrm{bc}}$ & $20.06 \pm 1.51^{\mathrm{ab}}$ \\
\hline $1,000 \mathrm{ppm}$ & $14.67 \pm 3.96^{\mathrm{c}}$ & $19.04 \pm 3.17^{b}$ \\
\hline \multicolumn{3}{|l|}{ (B) } \\
\hline Control & $20.47 \pm 1.48^{2) a b 3)}$ & $19.81 \pm 2.85^{\mathrm{a}}$ \\
\hline $20^{\circ} \mathrm{C}$ & $22.74 \pm 1.13^{\mathrm{a}}$ & $19.06 \pm 1.49^{\mathrm{a}}$ \\
\hline $25^{\circ} \mathrm{C}$ & $20.94 \pm 1.56^{\mathrm{ab}}$ & $19.75 \pm 1.82^{\mathrm{a}}$ \\
\hline $30^{\circ} \mathrm{C}$ & $18.26 \pm 2.93^{\mathrm{b}}$ & $18.54 \pm 2.62^{\mathrm{a}}$ \\
\hline $35^{\circ} \mathrm{C}$ & $21.10 \pm 0.74^{\mathrm{ab}}$ & $17.64 \pm 1.82^{\mathrm{a}}$ \\
\hline $40^{\circ} \mathrm{C}$ & $18.66 \pm 1.55^{\mathrm{b}}$ & $18.29 \pm 1.50^{\mathrm{a}}$ \\
\hline
\end{tabular}

A, antimicrobial activities by concentration of oxidant addition; B, antimicrobial activities by oxidant reaction temperature.

${ }^{1)}$ Cat, catazyme; Hyp, hydrogen peroxide.

${ }^{2)}$ All values are mean $\pm \mathrm{SD}(\mathrm{n}=3)$.

${ }^{3)}$ Means in the same column followed by different letters are significantly different $(\mathrm{p}<0.05, \mathrm{a}>\mathrm{b}>\mathrm{c})$.
소하였으며, 과산화수소 처리구는 유의적 차이를 보이지 않 았다. 하지만 $1,000 \mathrm{ppm}$ 농도에서는 두 처리구 모두 활성이 저해되는 것을 확인할 수 있었다. catazyme효소와 과산화수 소의 처리 온도에 따른 항균활성 측정 결과는 Table 7B와 같 다. 처리 온도별 결과에서 catazyme효소 처리구는 온도별 유 의성이 없었고, 과산화수소 처리구는 처리하지 않은 대조구 와 비교해 모든 시료구에서 유의적 차이를 보이지 않았다. 따 라서 catazyme효소와 과산화수소 처리에 따른 매실 ethanol $30 \%$ 추출물 항균활성은 크게 영향을 받지 않을 것으로 판단 된다.

\section{유기물 분해효소 처리에 따른 안정성}

S. mutans 균주는 치아에 충치를 유발하는 균주로서(Lee 등, 1993) 본 연구에서 선발된 매실 소재를 직접 식품으로 섭취할 경우에 S. mutans 균주를 억제하는 효과가 있겠지만, 활용 가치를 넓히는 측면에서는 다양한 치아 세정제 제조에 도 활용될 가능성이 있을 것으로 판단되었다. 현재 제조되 고 있는 치아 세정제에는 항균활성 소재가 첨가되고, 또한 음식물에 포함된 유기물을 분해할 수 있는 효소들이 첨가된 다(Cho 등, 2017; Kim 등, 2003b). 첨가된 효소는 유기물을 분해하는 역할을 하지만, 첨가된 항균활성 소재와 혼합되면 서 소재의 활성을 낮출 가능성이 있을 것으로 판단되었다. 따라서 각종 유기물 분해효소 처리에 따른 매실 소재의 $S$. mutans 균주의 항균활성을 평가하였다. 유기물 분해 효소 첨가 농도에 따른 매실 $30 \%$ ethanol 추출물의 S. mutans 균 주 항균활성 측정 결과는 다음 Table $8 \mathrm{~A}$ 와 같다. 본 실험에 서는 탄수화물 분해효소 6종(Fun, fungamyl; Ter, termamyl; Sec, secura; Lac, lactozym; Mal, maltoginase; Inv, invertase) 과 단백질 분해효소 2종(Fla, flavourzyme; Alc, alcalase), 지 방 분해효소 1 종(Lip, lipozyme)으로 구성해서 매실 소재의 S. mutans 균주의 항균활성을 측정하였다. 측정 결과, 10 종 의 효소 모두 $10 \mathrm{ppm}$ 과 $100 \mathrm{ppm}$ 농도 처리구에서는 활성이 대조구와 유의적 차이를 보이지 않았고, $1,000 \mathrm{ppm}$ 농도에 서는 대조구에 비해서 약간 활성이 줄어들었지만 13.81$17.58 \mathrm{~mm}$ 의 활성을 보여 높은 활성이 유지되는 것으로 판단 된다. 유기물 분해효소 처리 온도에 따른 매실 $30 \%$ ethanol 추출물의 S. mutans 균주에 항균활성을 측정한 결과는 Table $8 \mathrm{~B}$ 와 같다. 선행연구 결과인 효소 처리농도에 따른 항균활 성 실험에서 활성이 떨어지지 않았던 $100 \mathrm{ppm}$ 농도로 일괄 적으로 조정하고, 온도를 $20-40^{\circ} \mathrm{C}$ 범위로 각각 처리해서 온 도에 따른 활성을 평가하였다. 효소 반응 온도를 $20^{\circ} \mathrm{C}, 25^{\circ} \mathrm{C}$, $30^{\circ} \mathrm{C}, 35^{\circ} \mathrm{C}$ 및 $40^{\circ} \mathrm{C}$ 로 각각 처리하고, 활성을 측정한 결과, 모든 온도 처리군에서 대조구와 비교했을 때 유의적인 차이 를 보이지 않았다. 따라서 매실 ethanol $30 \%$ 추출물은 다양 
Table 8. Effect of various enzyme treatments on antimicrobial activity of $P$. mume fruit $\mathbf{3 0} \%$ ethanol extract against Streptococcus mutans KCCM 40105

(A)

\begin{tabular}{|c|c|c|c|c|c|c|c|c|c|}
\hline \multirow{2}{*}{ Sample } & \multicolumn{9}{|c|}{ Clear zone on plate $(\mathrm{mm})(11.48 \mathrm{mg} / \mathrm{mL})$} \\
\hline & Fun $^{1)}$ & Ter & $\mathrm{Sec}$ & $\mathrm{Lac}$ & Mal & Inv & Fla & Alc & Lip \\
\hline Control & $\begin{array}{c}20.12 \\
\pm 1.57^{2) \mathrm{a} 3)}\end{array}$ & $\begin{array}{r}19.89 \\
\pm 2.55^{\mathrm{a}}\end{array}$ & $\begin{array}{c}20.17 \\
\pm 4.11^{\mathrm{ab}}\end{array}$ & $\begin{array}{l}19.82 \\
\pm 1.33^{\mathrm{a}}\end{array}$ & $\begin{array}{c}19.68 \\
\pm 0.29^{\mathrm{a}}\end{array}$ & $\begin{array}{l}20.77 \\
\pm 1.42^{\mathrm{a}}\end{array}$ & $\begin{array}{c}19.99 \\
\pm 0.90^{\mathrm{a}}\end{array}$ & $\begin{array}{l}21.17 \\
\pm 2.07^{\mathrm{a}}\end{array}$ & $\begin{array}{l}19.11 \\
\pm 0.67^{\mathrm{ab}}\end{array}$ \\
\hline $10 \mathrm{ppm}$ & $\begin{array}{l}18.94 \\
\pm 1.39^{\mathrm{a}}\end{array}$ & $\begin{array}{c}18.48 \\
\pm 1.47^{\mathrm{ab}}\end{array}$ & $\begin{array}{l}20.81 \\
\pm 2.84^{\mathrm{a}}\end{array}$ & $\begin{array}{l}20.03 \\
\pm 1.56^{\mathrm{a}}\end{array}$ & $\begin{array}{l}20.65 \\
\pm 0.86^{\mathrm{a}}\end{array}$ & $\begin{array}{c}18.78 \\
\pm 1.04^{\mathrm{ab}}\end{array}$ & $\begin{array}{l}19.40 \\
\pm 2.09^{\mathrm{a}}\end{array}$ & $\begin{array}{r}18.81 \\
\pm 1.47^{\mathrm{ab}}\end{array}$ & $\begin{array}{c}20.24 \\
\pm 0.95^{\mathrm{a}}\end{array}$ \\
\hline 100 ppm & $\begin{array}{c}19.38 \\
\pm 1.40^{\mathrm{a}}\end{array}$ & $\begin{array}{c}17.20 \\
\pm 1.70^{\mathrm{ab}}\end{array}$ & $\begin{array}{c}17.33 \\
\pm 1.46^{\mathrm{ab}}\end{array}$ & $\begin{array}{l}18.08 \\
\pm 0.86^{\mathrm{a}}\end{array}$ & $\begin{array}{r}19.01 \\
\pm 1.50^{\mathrm{ab}}\end{array}$ & $\begin{array}{c}19.76 \\
\pm 0.60^{\mathrm{ab}}\end{array}$ & $\begin{array}{c}20.10 \\
\pm 1.12^{\mathrm{a}}\end{array}$ & $\begin{array}{l}18.08 \\
\pm 1.22^{\mathrm{b}}\end{array}$ & $\begin{array}{c}18.53 \\
\pm 0.21^{\mathrm{b}}\end{array}$ \\
\hline $1,000 \mathrm{ppm}$ & $\begin{array}{c}13.81 \\
\pm 0.67^{b}\end{array}$ & $\begin{array}{c}15.09 \\
\pm 1.28^{b}\end{array}$ & $\begin{array}{c}14.48 \\
\pm 0.66^{\mathrm{b}}\end{array}$ & $\begin{array}{l}16.36 \\
\pm 2.25^{\mathrm{a}}\end{array}$ & $\begin{array}{c}17.58 \\
\pm 0.48^{b}\end{array}$ & $\begin{array}{c}17.36 \\
\pm 1.71^{\mathrm{c}}\end{array}$ & $\begin{array}{l}19.35 \\
\pm 0.97^{\mathrm{a}}\end{array}$ & $\begin{array}{l}15.06 \\
\pm 0.68^{\mathrm{c}}\end{array}$ & $\begin{array}{l}16.60 \\
\pm 0.23^{\mathrm{c}}\end{array}$ \\
\hline \multicolumn{10}{|l|}{ (B) } \\
\hline Control & $\begin{array}{l}20.81 \\
\pm 1.44^{\mathrm{a}}\end{array}$ & $\begin{array}{l}20.89 \\
\pm 0.26^{\mathrm{a}}\end{array}$ & $\begin{array}{l}20.38 \\
\pm 0.52^{\mathrm{a}}\end{array}$ & $\begin{array}{c}20.84 \\
\pm 3.08^{\mathrm{a}}\end{array}$ & $\begin{array}{l}20.13 \\
\pm 0.74^{\mathrm{a}}\end{array}$ & $\begin{array}{l}20.72 \\
\pm 0.52^{\mathrm{a}}\end{array}$ & $\begin{array}{l}20.48 \\
\pm 2.21^{\mathrm{a}}\end{array}$ & $\begin{array}{l}20.00 \\
\pm 1.42^{\mathrm{a}}\end{array}$ & $\begin{array}{c}20.34 \\
\pm 1.47^{\mathrm{a}}\end{array}$ \\
\hline $20^{\circ} \mathrm{C}$ & $\begin{array}{l}20.97 \\
\pm 3.28^{\mathrm{a}}\end{array}$ & $\begin{array}{c}18.47 \\
\pm 1.03^{\mathrm{ab}}\end{array}$ & $\begin{array}{l}19.31 \\
\pm 1.48^{\mathrm{a}}\end{array}$ & $\begin{array}{l}18.62 \\
\pm 1.74^{\mathrm{a}}\end{array}$ & $\begin{array}{l}18.36 \\
\pm 2.54^{\mathrm{a}}\end{array}$ & $\begin{array}{l}20.12 \\
\pm 1.02^{\mathrm{a}}\end{array}$ & $\begin{array}{l}20.12 \\
\pm 3.28^{\mathrm{a}}\end{array}$ & $\begin{array}{l}18.92 \\
\pm 3.32^{\mathrm{a}}\end{array}$ & $\begin{array}{c}20.48 \\
\pm 1.29^{\mathrm{a}}\end{array}$ \\
\hline $25^{\circ} \mathrm{C}$ & $\begin{array}{l}21.08 \\
\pm 2.87^{\mathrm{a}}\end{array}$ & $\begin{array}{l}18.12 \\
\pm 1.56^{\mathrm{b}}\end{array}$ & $\begin{array}{l}17.77 \\
\pm 2.57^{\mathrm{a}}\end{array}$ & $\begin{array}{c}19.58 \\
\pm 1.25^{\mathrm{a}}\end{array}$ & $\begin{array}{l}18.42 \\
\pm 1.31^{\mathrm{a}}\end{array}$ & $\begin{array}{l}21.00 \\
\pm 0.34^{\mathrm{a}}\end{array}$ & $\begin{array}{l}20.17 \\
\pm 1.75^{\mathrm{a}}\end{array}$ & $\begin{array}{l}19.00 \\
\pm 2.99^{\mathrm{a}}\end{array}$ & $\begin{array}{l}19.64 \\
\pm 0.86^{\mathrm{a}}\end{array}$ \\
\hline $30^{\circ} \mathrm{C}$ & $\begin{array}{l}20.91 \\
\pm 1.30^{\mathrm{a}}\end{array}$ & $\begin{array}{c}18.33 \\
\pm 1.88^{\mathrm{ab}}\end{array}$ & $\begin{array}{l}19.81 \\
\pm 1.22^{\mathrm{a}}\end{array}$ & $\begin{array}{c}19.02 \\
\pm 1.01^{\mathrm{a}}\end{array}$ & $\begin{array}{l}19.56 \\
\pm 1.05^{\mathrm{a}}\end{array}$ & $\begin{array}{l}20.57 \\
\pm 0.72^{\mathrm{a}}\end{array}$ & $\begin{array}{l}22.37 \\
\pm 2.26^{\mathrm{a}}\end{array}$ & $\begin{array}{c}18.33 \\
\pm 1.93^{\mathrm{a}}\end{array}$ & $\begin{array}{l}20.91 \\
\pm 1.08^{\mathrm{a}}\end{array}$ \\
\hline $35^{\circ} \mathrm{C}$ & $\begin{array}{l}21.02 \\
\pm 2.84^{\mathrm{a}}\end{array}$ & $\begin{array}{c}18.95 \\
\pm 1.21^{\mathrm{ab}}\end{array}$ & $\begin{array}{l}19.17 \\
\pm 0.77^{\mathrm{a}}\end{array}$ & $\begin{array}{l}18.47 \\
\pm 2.81^{\mathrm{a}}\end{array}$ & $\begin{array}{l}18.63 \\
\pm 1.70^{\mathrm{a}}\end{array}$ & $\begin{array}{l}19.59 \\
\pm 1.66^{\mathrm{a}}\end{array}$ & $\begin{array}{l}19.65 \\
\pm 0.95^{\mathrm{a}}\end{array}$ & $\begin{array}{l}19.14 \\
\pm 1.99^{\mathrm{a}}\end{array}$ & $\begin{array}{l}19.44 \\
\pm 1.74^{\mathrm{a}}\end{array}$ \\
\hline $40^{\circ} \mathrm{C}$ & $\begin{array}{l}21.90 \\
\pm 2.44^{\mathrm{a}}\end{array}$ & $\begin{array}{c}18.70 \\
\pm 1.40^{\mathrm{ab}}\end{array}$ & $\begin{array}{l}18.15 \\
\pm 2.58^{\mathrm{a}}\end{array}$ & $\begin{array}{c}19.06 \\
\pm 1.69^{\mathrm{a}}\end{array}$ & $\begin{array}{c}19.62 \\
\pm 1.46^{\mathrm{a}}\end{array}$ & $\begin{array}{l}20.35 \\
\pm 0.72^{\mathrm{a}}\end{array}$ & $\begin{array}{c}19.73 \\
\pm 1.10^{\mathrm{a}}\end{array}$ & $\begin{array}{l}19.15 \\
\pm 1.30^{\mathrm{a}}\end{array}$ & $\begin{array}{l}19.58 \\
\pm 1.82^{\mathrm{a}}\end{array}$ \\
\hline
\end{tabular}

A, antimicrobial activities by concentration of enzyme addition; B, antimicrobial activities by enzyme reaction temperature.

${ }^{1)}$ Fun, fungamyl; Ter, termamyl; Sec, secura; Lac, lactozym; Mal, maltoginase; Inv, invertase; Fla, flavourzyme; Alc, alcalase; Lip, lipozyme.

${ }^{2)}$ All values are mean $\pm \mathrm{SD}(\mathrm{n}=3)$.

${ }^{3)}$ Means in the same column followed by different letters are significantly different $(p<0.05, a>b>c)$.

한 유기물 분해 효소의 처리 온도에 영향을 받지 않는 것을 확인할 수 있었다. 처리 온도를 $20-40^{\circ} \mathrm{C}$ 범위로 설정한 이유 는 치아 세정제 사용 시, 일반적으로 실온에서 사용되기 때문 에 실온 범위내에 포함되는 온도의 범위로 설정하였다.

\section{요 약}

본 연구에서는 Streptococcus mutans KCCM 40105 균주 의 항균활성 효과가 있는 천연 소재를 선발하고, 효율적인 추출 조건을 확인하였으며, 활성 물질이 다양한 처리 조건 에서 안정성이 있는지 확인하였다. 총 10 종의 식품 소재 후 보군에서 S. mutans 균주에 항균활성을 보인 소재는 매실만 이 활성을 보여 최종 소재로 선발하였다. 추출 용매별 항균 활성은 ethanol 추출물에서 $18.66 \mathrm{~mm}$, water 추출물에서
$20.18 \mathrm{~mm}$ 의 활성을 보였다. 이 두 용매의 농도에 따른 항균 활성을 측정한 결과, $30 \%$ ethanol 추출물 농도에서 20.49 $\mathrm{mm}$ 로 가장 높은 활성을 보였다. 최소저해농도를 측정한 결 과, $3.0 \mathrm{mg} / \mathrm{mL}$ 농도에서 활성을 보였고, 매실 $30 \%$ ethanol 추출물에 포함된 활성 물질의 열 및 $\mathrm{pH}$ 안정성을 측정한 결 과, 열에는 안정성이 확인되었으나, $\mathrm{pH}$ 안정성에서는 $\mathrm{pH}$ 6.0 이상부터는 활성이 나타나지 않았다. 매실 $30 \%$ ethanol 추출물의 유기물 분해효소 처리에 따른 항균활성 평가는 탄 수화물, 단백질, 지방 분해효소 모두 $10 \mathrm{ppm}$ 과 $100 \mathrm{ppm}$ 의 농도에서는 큰 영향을 보이지 않았으나, $1,000 \mathrm{ppm}$ 농도에 서 활성이 다소 감소하는 경향을 보였다. Catazyme 효소와 과산화수소의 처리에 따른 활성을 측정한 결과, $10 \mathrm{ppm}$ 의 저농도에서는 활성이 증가하였으나, 처리 농도가 $100 \mathrm{ppm}$ 이상부터는 활성이 감소하였고, 처리 온도별 활성은 유의적 
차이를 보이지 않았다.

\section{감사의 글}

본 연구는 한국산업기술진흥원(과제번호: P063500057)의 연구비 지원을 받아 실행한 결과의 일부로 이에 감사드립니다.

\section{Conflict of interests}

The authors declare no potential conflict of interest.

\section{ORCID}

Bok-Seon Kim https://orcid.org/0000-0002-9094-3250

Chang Ki Huh https://orcid.org/0000-0003-4456-8477

\section{References}

Aye A. Comparative study about in vitro culture conditions of leaf and leaf callus of basil (Ocimum basilicum L.) and its antibacterial activity. MS Thesis, Jeonbuk National University, Korea, p 1-5 (2016)

Cho JW, Kim BY, Choi SJ, Jeong JB, Kim HS. Change in amygdalin contents of Maesil (Prunus mume) wine according to preparation steps and its characteristics. Korean J Food Sci Technol, 51, $42-47$ (2019)

Cho MH, Kim R, Yu SH. A research on satisfaction of toothpaste added natural herbal extracts. J Tech Dent, 39, 111-118 (2017)

Choi BBR, Yun SE, Park SR, Kim GC. Effectiveness of mentha extracts against oral microorganisms: An in vitro study. J Korean Acad Oral Health, 44, 67-72 (2020)

Choi MY, Won HR, Park HJ. Antimicrobial activities of Maesil (Prunus mume) extract. Korean J Community Living Science, 15, 61-66 (2004)

Do DS, Lee SM, Na MK, Bae KH. Antimicrobial activity of medicinal plant extracts against a cariogenic bacterium, Streptococcus mutans OMZ 176. Kor J Pharmacogn, 33, 319-323 (2002)

Ha MH, Park WP, Lee SC, Choi SG, Cho SH. Antimicrobial characteristic of Prunus mume extract. Korean J Food Preserv, 13, 198-203 (2006)

Hamada S, Koga T, Ooshima T. Virulence factors of Streptococcus mutans and dental caries prevention. J
Dent Res, 63, 407-411 (1984)

Jang JH, Kim YI, Lee H. Antimicrobial activity of Prunus mume extract to oral microbes. J Korean Soc Dent Hyg, 14, 109-115 (2014)

Kim HJ, Lee JW, Kim YD. Antimicrobial activity and antioxidant effect of Curcuma longa, Curcuma aromatica and Curcuma zedoaria. Korean J Food Preserv, 18, 219-225 (2011a)

Kim JH, Kim MJ, Choi SK, Bae SH, An SK, Yoon YM. Antioxidant and antimicrobial effects of lemon and eucalyptus essential oils against skin floras. J Soc Cosmet Scientists Korean, 37, 303-308 (2011b)

Kim KC, Bae YS, Kim SW, Kim SJ. Production of amylase by a filamentous fungus, strain FM04, and enzymatic hydrolysis of food waste. Korean J Biotechnol Bioeng, 18, 363-370 (2003b)

Kim YS, Park YS, Lim MH. Antimicrobial activity of Prunus mume and Schizandra chinenis H-20 extracts and their effects on quality of functional Kochujang. Korean J Food Sci Technol, 35, 893-897 (2003a)

Ko MS, Yang JB. Antimicrobial activities of extracts of Prunus mume by sugar. Korean J Food Preserv, 16, 759-764 (2009)

Lee CE, Jo JK, Kim JD, Lee DG, Kim WS, Lee SH. Verification of antibacterial activities of oriental herbal medicine extracts. J Life Sci, 27, 611-616 (2017)

Lee JS. Antimicrobial effect of Prunus mите extract against Streptococcus mutans and Streptococcus sobrinus. MS Thesis, Chonnam National University, Korea (2014)

Lee KW. Antibacterial activity of the Zingiberaceae plant extract against oral microorganisms. MS Thesis, Yonsei University, Korea, p 23 (2005)

Lee KY, Cho HS, Yoon JW, Hae TR. Study on the development of preventive agent of dental caries from biological active materials: I. Development of disc PAHA for an artificial tooth and preventive effect on dental caries from plant extracts. Korean J Biotechnol Bioeng, 8, 126-132 (1993)

Lee OK, Lee HJ, Shin YS, Ahn YG, Jo HJ, Shin HC, Kang HY. Quantitative analysis of the fruit flesh of Prunus mume Siebold \& Zuccarni. Korean J Medicinal Crop Sci, 15, 143-147 (2007)

Lee SE, Park CG, Cha MS, Kim JK, Seong NS, Bang KH, Bang JK. Antimicrobial activity of essential oils from 
Mentha arvensis L. var. piperascens Malivaud and Agastache rugosa O. Kuntze on Escherichia coli and Salmonella typhimurium. Korean J Mecidinal Crop Sci, 10, 206-211 (2002)

Lim JW, Lee GB. Studies on the antimicrobial activities of Prunus mume. J East Asian Soc Dietary Life, 9, 442-451 (1999)

Moon YH, Lee YH, Min BS, Bae KH. Antibacterial constituents from Scutellariae Radix against Streptococcus mutans OMZ176. Kor J Pharmacogn, 28, 99-103 (1997)

Park KS, Park HW, Shin IS, Lee JH, Seo HW. Study on comparison of antimicrobial activity between horseradish (Armoracia rusticana) root extracts and synthetic allyl isothiocyanate against oral pathogenic microorganisms. J Korean Acad Pediatr Dent, 36, 217-226 (2009)

Park LY, Chae MH, Lee SH. Antibacterial activity of fresh Prunus mume and Prunus mume liqueur byproduct. J Food Hyg Saf, 22, 77-81 (2007)

Seo KS, Huh CK, Kim YD. Comparison of animicrobial and antioxidant activities of Prunus mume fruit in different culutivars. Korean J Food Preserv, 15, 288-292 (2008)
Seo YH. Antioxidant and antimicrobial activities of ginger with aging and fermentation. Korean J Food Preserv, 24, 1180-1187 (2017)

Sheo HJ. The antibacterial action of garlic, onion, ginger and rad pepper juice. J Korean Soc Food Sci Nutr, 28, 94-99 (1999)

Shin TY, Kim DK. Antiallergic activity of menthae herba. Kor J Pharmacogn, 29, 248-253 (1998)

Yoon JW, Yoo MY, Choi JH, Lee MK, Oh DH. Antimicrobial effects of ethanol-extracted and subfractionated materials from different parts of Quercus aliena Blume. J Korean Soc Food Sci Nutr, 34, 910-914 (2005)

Yu NY, Park HW, Lee JH, Seo HW. The antimicrobial effect of Horseradish (Armoracia rusticana) root extracts against oral pathogens. J Korean Acad Pediatr Dent, 33, 447-456 (2006)

Yun SM, Jung JH, Lee JS. Isolation and identification of an antibacterial substance from sea mustard, Undaria pinnatifida, for Streptococcus mutans. J Korean Soc Food Sci Nutr, 36, 149-154 (2007) 